\title{
Institution Wide Reform Through NSF Supported Projects
}

\author{
Jack L. Waintraub, P.E. \\ Middlesex County College
}

\section{Middlesex County College is Preparing for the 21st Century}

Institutional reform efforts at Middlesex County College are multi-pronged efforts that engage faculty across disciplines in cooperation with other community colleges, four-year institutions and local school districts. The College has forged alliances with business, pre-college educators, and other colleges to increase the level of college preparedness of school populations, revise and streamline curricula among applied academic populations, devise strategies for increasing enrollments from underrepresented populations, integrate technology into instruction, offer students cooperative and intern experiences, and increase the general level of communication across disciplines.

With support from the National Science Foundation, Middlesex County College, is making significant progress towards achieving its goals. Under the New Jersey Center for Advanced Technological Education, led by Middlesex County College, a consortium of institutions is restructuring engineering technician education by creating a new interdisciplinary technician program in Mecomtronics Engineering Technology. Likewise, a program in Telemedia Communications Technology is being developed to educate technicians for the rapidly expending telecommunications field.

The Institution has also made a commitment to revitalizing mathematics and science education, and in particular, to addressing the needs of non-science students. Instruction will be organized around broad themes reflective of the current scientific and technological issues facing society today.

The development and implementation of new, and the restructuring of existing curricula are a consorted effort of faculty and administration to improve mathematics, science and technical education. Barriers that traditionally prevented significant changes to occur at institutions are being removed in order to more effectively respond to the needs of the populations that we serve.

\section{The New Jersey Center for Advanced Technological Education}

Prompted by concerns about declining U.S. industrial competitiveness, the last decade has seen a growing number of efforts to assure the development of a multi-faceted U.S. technical workforce that is well prepared to function effectively in a global economy. As we turn to technology to find answers for many of life's challenges, we realize that a better educated technological workforce is essential to achieving the desired position in this global economy. In 1995, Middlesex County College located in Edison, New Jersey, with support from the National Science Foundation and in partnership with two and four-year institutions, a secondary school district, industry, and professional societies, established the New Jersey Center for Advanced Technological Education (NJCATE). The Center is developing 
strategies that will strengthen two-year college engineering technician education. Additionally, the Center is working to improve secondary school level education and to enhance the opportunities for interested students to pursue advanced technician education. NJCATE is developing a new Mecomtronics Engineering Technology Program. This new associate degree program will provide a broad base of skills from MEchanical, COMputer,

TeleCOMmunications and ElecTRONICS technologies. The Mecomtronics program is designed to meet industry's need for multifunctional engineering technicians and to meet the individual student's need for knowledge and capabilities that will enhance life-long learning in a changing world.

Integral to the curriculum model are techniques and methods employed by industry and business in providing quality products and services to their customers. The concurrent educational delivery aspect of the model mirrors industry's "just-in-time" (JIT) approach to product development. Just-in-time refers to the context in which core discipline subject matter is delivered. Rather than presentation of theoretical concepts followed by application, JIT postulates concurrent instruction in theory and application within the context of realistic projects or problems. Where possible, instruction is based on projects provided by industry partners or designed by faculty in collaboration with industry representatives, with students assuming greater responsibility for their own learning. Work experiences for students will play an important role, and a wide range of instructional methods and tools will be employed, making use of advanced instructional technologies to develop critical thinking skills, work ethics, social values, and team participation, as well as leadership qualities. Emphasis will be placed on developing the skills that allow students to function as team members on group projects, to write effective memoranda and reports, to give clear and concise oral presentations, and to make timely and cost-effective decisions based on social, environmental and ethical considerations. The Mecomtronics Engineering Technology Associate Degree program will admit the first class of students in the Fall of 1998.

\section{Telemedia Communications Technology}

Linked to the Center activities is another NSF-sponsored project that focuses on the development of a Telemedia Communications Technology program. This associate degree program is being specifically designed to serve the growing Telecommunications industry, by preparing technicians who will be skilled in the operation, installation and maintenance of systems and equipment involved in the transmission of multimedia information over distances. Current and future demand for technicians who posses these skills is being articulated to us by industry representatives who are essential contributors to the development of the curriculum.

The Telemedia Communications curriculum, like the Mecomtronics program, is competencybased and designed around industrial type projects. Faculty across several departments are working collaboratively to develop this curriculum. Due to the interdisciplinary nature of this program, expertise was brought together from the areas of engineering technology, information systems, and graphic arts, as well as the core study areas of mathematics, science and communications. A local high school is also a partner in this project to develop activities at the secondary school level that will enhance the preparation of students for entry to the AAS 
program. Articulation with four-year institutions is being pursued for transfer opportunities to various programs. The Telemedia Communications Technology Associate Degree program will also admit its first class of students in the Fall of 1998.

\section{Revitalizing Mathematics and Science}

Middlesex County College is also the recipient of an Institutional Reform grant from the National Science Foundation to revitalize science and mathematics education. This institutional reform effort particularly focuses on the needs of non-science and non-technical majors. This effort will take a thematic systems approach to the delivery of mathematics, science, and technology education. This structure requires interdisciplinary development and delivery to foster in students an understanding of the critical role that mathematics, science and technology play in society, as well as the nature of mathematics and science endeavors. The overall strategy will be to engage students in investigation of pertinent issues and problems that will require application of mathematics and science concepts.

The restructured curricula will provide students with opportunities for learning mathematics, science and technology that are relevant and meaningful. As a result, students will have a better understanding of and be more likely to continue to learn and read about current issues in which the sciences and technology play major roles and will be capable of making informed decisions regarding scientific and technological questions.

Instruction will be organized around broad themes reflective of the crucial scientific and technological issues facing society today. Six specific themes have been identified: Energy, Transportation, Space, The Environment, The Human Body, and Telecommunications. These themes share several key characteristics. All are systems-related, all involve several science disciplines and mathematics, as well as technology, and all involve key social issues.

A critical element is the engagement of faculty from mathematics, science, technical, and humanities disciplines in the design, development and implementation of the projected curricula. The overall plan is to develop a series of module-based courses for each theme. Faculty, working in interdisciplinary teams will create, pilot-test and implement the courses which will incorporate instruction in mathematics, science and technology within the context of the themes. These integrated offerings will replace current choices for non-science/non-technical majors.

The course development efforts are currently concentrated on two of the themes, The Environment and Energy. Pilot testing of the courses will begin in the Fall of 1997.

\section{Creating Institutional Reform}

The three projects described above are supported by the National Science Foundation (NSF) Advanced Technological Education (ATE) and The Institutional Reform (IR) programs. The funding from NSF serves as a catalyst for wide-sweeping changes in Science, Mathematics, Engineering and Technology education (SMET) at Middlesex County College. Strong commitment from upper administration is essential in such an endeavor. Equally important is the 
participation of all collage entities in carrying out the projects. Perhaps, the most crucial element is faculty recognition of needed changes and willingness to work towards their implementation.

These efforts are bringing together interdisciplinary groups of faculty to work together across departmental lines to create teams of curricula designers, developers, and implementors that might otherwise not occur. Faculty development is a strong component of these projects. The knowledge gained is applied directly to improve the education of students. The alliances forged with other academic institutions, are bringing together educators in many meaningful ways. Secondary school educators are working with two- and four-year faculty to effect a seamless transition in a life-long learning process. The essential linkages of academia with business and industry are being accomplished through active involvement of industry personnel, where they can participate in the education of their future employees. Change is not embraced by everyone. However, engaging administrators and faculty within the institutions and across institutions and in partnership with business and industry in a process that sets the course for change provides opportunities that can excite and invigorate an institution.

Bibliography

Collins, Timothy W., Gentry, Don K., and Crawley, Veronica O., Co-chairs. Gaining the Competitive Edge: Critical Issues in Science and Engineering Technician Education. A Report from the Workshop Sponsored by the National Science Foundation, July 1993.

George, Melvin D., Chair. Shaping The Future: New Expectations for Undergraduate Education in Science, Mathematics, Engineering and Technology. A Report on its Review of Undergraduate Education sponsored by the National Science Foundation, July 1996.

A National Agenda for the Future of Engineering Technician Education. Workshop Report, Sinclair Community College, Dayton, Ohio, January 1997.

Biography

JACK L. WAINTRAUB, P.E. is Professor/Chairman of the Physics/Electrical Engineering Technology Department at Middlesex County College; Director of the New Jersey Center for Advanced Technological Education; author of several textbooks in Electrical Engineering Technology; previously chaired the Electrical Engineering Technology Department Heads Association; member of the Education Activities Board of IEEE; served as a Program Director at the NSF during 1993-1994 in the Division of Undergraduate Education; also a past member of the TAC/ABET Commission; Senior Member of IEEE; and a member of ASEE. 